\title{
Fiscal Policy And Economic Growth In PIIGS Countries: An Empirical Assessment
}

Helmi Hamdi, CERGAM-CAE (4225), Aix-Marseille University, France

Rashid Sbia, Solvay Business and Economics School and Ministry of Finance, Kingdom of Bahrain

\begin{abstract}
This paper studies the dynamic relationships between government revenues, government expenditures and economic growth in Portugal, Italy, Ireland, Greece and Spain (PIIGS henceforth). To this end we use a multivariate econometric model based on the Toda-Yamamoto (1995) procedure. Our empirical results reveal a bidirectional relationship between government revenues and government expenditures in Portugal only. Greece is the only county in which government expenditures Granger cause government revenues. Therefore, there is no evidence for spend-and-tax hypothesis for three countries of our sample. For Italy there is a unique unidirectional relationship running from government revenues to GDP while a unique unidirectional relationship was found running from government revenues to government expenditures for Ireland. Results for Spain show a double bidirectional relationships running from government revenues to GDP and from government expenditures to GDP. Moreover, there exists a unidirectional causal relationship between government revenues and government expenditures. Again, there is no evidence for tax-and-spend hypothesis for three countries of our sample.
\end{abstract}

Keywords: Fiscal Policy; PIIGS; Toda-Yamamoto; Granger Causality

\section{INTRODUCTION}

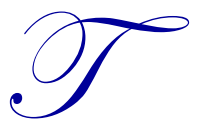

he effect of fiscal policy on economic growth is an ambiguous and long-standing issue in both theoretical and empirical research. It is also of critical importance for policymakers as they actively use fiscal policies to correct externalities and ensure satisfactory provision of public goods and services. Nevertheless, in practice, it is difficult to define the optimal policy because the reaction may differ from one country to another.

During the past few decades, literature on public finance has distinguished various hypotheses to describe the relationship between government revenues and expenditures. Those hypotheses can be classified into four categories ${ }^{1}$. The first one is the tax-and-spend hypothesis proposed by Friedman (1978), Buchanan and Wagner (1978), which suggests that changes in revenues generate changes in expenditures. The authors argued that increases of tax will generate an increase in expenditures. The second assumption is the spend-and-tax hypothesis suggested by Peacock and Wiseman $(1961,1979)$ and Barro (1974) which reveals that changes in expenditures generates changes in revenues. The third hypothesis is fiscal synchronization early developed by the work of Musgrave (1966) and later developed by Meltzer and Richard (1981). This hypothesis assumes that government optimal fiscal policies rely on voters' decision process outcomes concerning their demand for public services and their reactions toward income redistribution (Manage and Marlow 1986; Miller and Russek 1990; Owoye 1995). Finally, the fourth hypothesis is institutional separation developed by Baghestani and McNown (1994) which considers that government revenues and expenditures are independent from each other. As there is no relationship between government revenues and expenditures, this hypothesis is characterized by non-causality in empirical terms.

\footnotetext{
${ }^{1}$ For more details, see recent paper of Hamdi and Sbia (2013).
} 
Literature on fiscal policy is abundant and results differ from one study to another. For the US context, Ramey and Shapiro (1998) found that after a short increase in government spending, nondurable consumption decline slightly while durables consumption falls. Fatás and Mihov (2001) show that increases in government expenditures are expansionary, but lead to important changes in the composition of GDP in the form of an increase in private investment that more than compensates for the fall in private consumption (Afonso and Ricardo 2009). Blanchard and Perotti (2002) find that fiscal shocks have a positive effect on private consumption, and a negative impact on private investment. Afonso and Ricardo (2009) investigated the macroeconomic effect of Fiscal policy on GDP; their results suggest that an expansion of government spending is associated to an episode of fiscal deterioration. Similarly, an increase in government revenue is followed by a somewhat less disciplined fiscal policy.

The 2008 financial turmoil and the ongoing sovereign debt crisis have renewed the interest of academia (i.e Kouretas and Vlamis (2010); Miroslav 2010, Hamdi and Sbia 2013), central bankers and governments in the role of fiscal policy. This is because the crisis shows how mismanagement of fiscal policy can be devastating for the welfare of a country and how effective fiscal policy is crucial for sustainable economic development. The current study enrich the available literature by exploring the dynamic relationships between government revenues, government expenditures and economic growth in PIIGS countries through the use of a multivariate causality framework based on the Toda-Yamamoto (1995) test, the so-called Modified-Wald test.

The reminder of the paper is as follows: section three describes data and the methodology, section four analyses the empirical results while section five concludes.

\section{FISCAL POLICY AND GROWTH: A LITERATURE REVIEW}

Literature on fiscal policy and economic growth is rich. The empirical research could be categorized in four axes. The first one explores the effects of budget deficits and fiscal consolidation on growth. Studies of this axe suggest that sustainable fiscal consolidation enforces investor confidence and creates budgetary resources for specific purpose without jeopardizing the sustainability of the government's financial position ${ }^{2}$, or the stability of the economy in the long-run. Results of the first axe are interpreted as evidence of non-Keynesian effects during fiscal consolidation episodes. Researchers have pointed to the experiences of Scandinavian countries where fiscal consolidations have been generated strong growth. Some other cross-country studies based on many periods of large reductions in deficits demonstrate that fiscal adjustments are frequently associated with stronger-than average GDP growth. For example, the study of Kumar et al. (2007) concludes that while fiscal consolidations tend to have short-run contractionary effects, they can be expansionary in the long-run. The second axe examines the impact of the size of government on growth (where the size of the government is defined as the general government spending in proportion to GDP). The idea is to show that an uncontrolled public spending could negatively affect growth and fiscal imbalances would lead to high levels of taxation and borrowing. As a result investors will not have any incentive to investor or to innovate. Uncontrolled public spending is an attraction for corrupted bureaucrats and free riders. Broadly, the relationship between government size and growth rates has received great deal of attention since the early 1990s, with the pioneering paper of Barro (1991b). In his seminal paper, Barro extends the endogenous growth framework including tax-financed government services (Barro and Sala-I-Martin 1992). He concludes that government expenditure is positively linked to economic growth when the share of government expenditure (and consequently the tax rate) is low. But then turns negative due to increasing inefficiencies as the share of expenditure increases (related to the disincentive effect of higher tax rates on private capital accumulation). Thus, indicating a nonlinear relationship between government expenditure and growth (Bayraktar and Moreno-Dodson 2010). These expenditures must be financed by two types of taxation: those (such as income taxes) that are distortionary with respect to investment decisions, including human capital investment, and taxes which do not distort investment decisions. The third axe focuses on the role of governance. The impact of fiscal policy on growth will depends on the efficiency and effectiveness of the policy makers' decisions and thus, the quality of their governance. The quality of governance and public institutions has a direct impact on public expenditures and thus on growth (Burnside and Dollar 2000, 2004). Countries with better governance are generally able to collect taxes and spend public funds more efficiently and effectively. Thus, higher spending in productive areas can lead to higher growth

\footnotetext{
${ }^{2}$ See Giavazzi and Pagano 1990, Alesina and Perotti 1997; Alesina and Ardagna 1998; Perotti 1999, Miller and Russek 2003, Gupta et al 2005
}

1344 Copyright by author(s) $\underline{\text { Creative Commons License CC-BY }}$

2013 The Clute Institute 
in countries with strong governance, and higher spending in unproductive areas is not necessarily harmful to growth. In contrast, growth in countries with weak governance tends to be slowed by higher levels of unproductive spending and the higher taxes that are required to fund it, and they do not necessarily benefit from spending in areas that are typically considered productive (Bayraktar and Moreno-Dodson. 2010). Finally, the fourth axe analysis the impact of the composition of expenditures and taxes on growth. Broadly, not all expenditures and methods of financing have the same impacts on economic growth. Empirical evidence suggests that growth is very sensitive to the composition of expenditures. Government spending that improves the quality and quantity of factors of production, enhances the quality of legal framework, reduces markets barriers highly increases growth. In contrast, unproductive spending (defense, subsidies) may considerably hit growth.

Since 2007, several developing and developing countries have been experiencing serious government budget deficits and their fiscal positions have been deteriorated substantially, reflecting declines in the level of GDP. Among these countries, PIIGS are on the top of the list. As illustrates in Figure 1, central government debt (as percentage of GDP) has increased drastically since 2007 in PIIGS countries. The debt to GDP ratio reached 110\% in Italy and 140\% in Greece in 2010.

Figure 1. Evolution of Central Government Debt in PIIGS countries since 2003 (as \% of GDP)

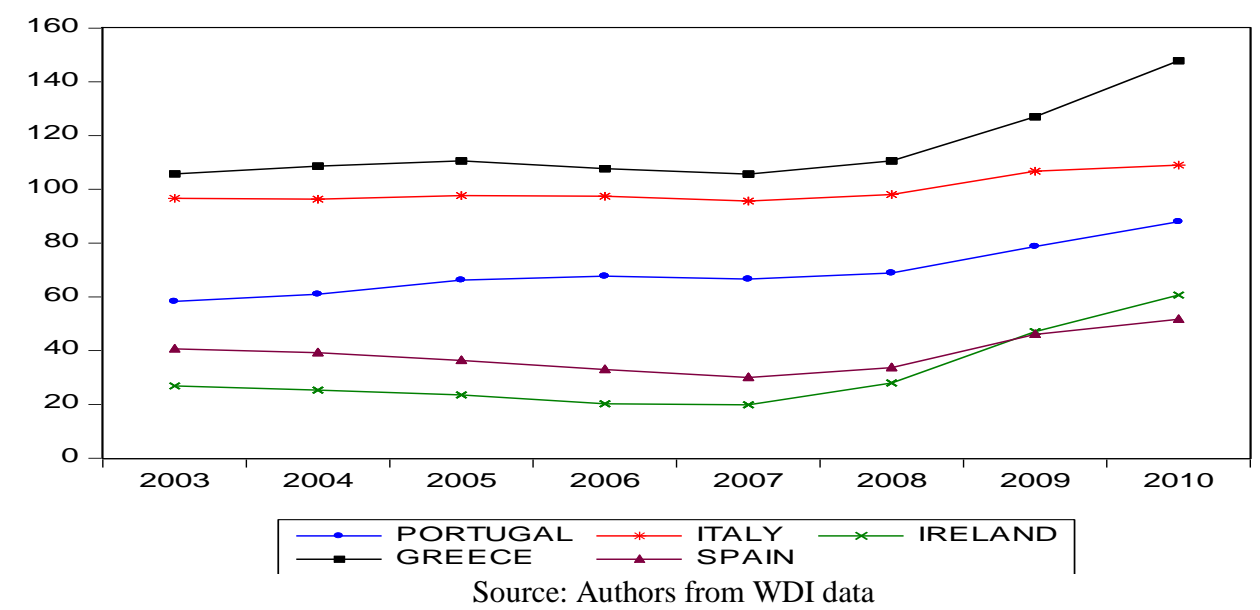

The current crisis shows how misconduct of fiscal policy can threaten the welfare of a country and how crucial effective fiscal policy is for economic development.

\section{DATA AND ECONOMETRIC METHODOLOGY}

This study uses annual real GDP, real government spending (GE) and real government revenues (GR) time series data covering the 1995-2009 periods for PIIGS countries ${ }^{3}$. All the data are taken from the Eurostat database, and the sample period is common for all countries.

\section{a. Unit Root Test}

To test for stationary of the series, we firstly, we employ an Augmented Dickey-Fuller (ADF) unit root test. The extended maintained regression used in the ADF test can be expressed in its most general form as follows:

$$
\Delta Y_{t}=\mu+\gamma Y_{t-1}+\sum_{j=1}^{p} \alpha_{j} \Delta Y_{t-j}+\beta t+\omega_{t}
$$

\footnotetext{
${ }^{3}$ This is the longest available time series at international databases (IMF, WDI, Eurostat, OECD)
} 
where $\mu$ is the drift term, $t$ denotes the time trend and $p$ is the largest lag length used. The null hypothesis $\mathrm{H}_{0}$ : $Y_{t}$ is $\mathrm{I}(1)$, that is unit root, is rejected in favor of $\mathrm{I}(0)$ if $\gamma$ is found to be negative and statistically significantly different from zero. Common criticisms of these tests include sensitivity to the way the test is conducted (size of test), such that the wrong version of the ADF test is used. ADF test are also relatively sensitive to any incorrect establishment of lag parameter. Furthermore, this test tends to under-reject the null hypothesis pointing at nonstationarity too often. Consequently, to confirm the results of the ADF test a Kwiatkowski-Phillips-Schmidt-Shin (KPSS) test was also conducted.

The KPSS statistic is based on the residuals from the OLS regression, which takes the following form:

$y_{\mathrm{t}}=\beta^{\prime} \mathrm{D}_{\mathrm{t}}+\mu_{\mathrm{t}}+u_{\mathrm{t}}$

$\mu_{\mathrm{t}}=\mu_{\mathrm{t}-1}+\varepsilon_{\mathrm{t}}, \quad \varepsilon_{\mathrm{t}} \sim W N\left(0, \sigma_{\varepsilon}^{2}\right)$

where $D_{t}$ contains deterministic components (constant or constant plus time trend), $u_{t}$ is $\mathrm{I}(0)$ and $\mu_{\mathrm{t}}$ may be heteroskedastic. Notice that is a pure random walk with innovation variance $\sigma_{\varepsilon}^{2}$. The null hypothesis that $y_{\mathrm{t}}$ is $\mathrm{I}(0)$ is formulated as $\mathrm{H}_{0}: \sigma_{\varepsilon}^{2}=0$, which implies that $\mu_{\mathrm{t}}$ is a constant. Although not directly apparent, this null hypothesis also implies a unit moving average root in the ARMA representation of $\Delta y_{\mathrm{t}}$. The KPSS test statistic is the Lagrange multiplier (LM) or score statistic for testing $\sigma_{\varepsilon}^{2}=0$ against the alternative that $\sigma_{\varepsilon}^{2}>0$ and is given by:

$K P S S=\left(T^{-2} \sum_{t=1}^{T} \hat{S}_{t}^{2}\right) / \hat{\lambda}^{2}$

where $\hat{S}_{t}^{2}=\sum_{j=1}^{T} \hat{u}_{j}, \hat{u}_{t}$ is the residual of a regression of $y_{\mathrm{t}}$ on $\mathrm{D}_{\mathrm{t}}$ and $\hat{\lambda}^{2}$ is a consistent estimate of the long-run variance of $u_{\mathrm{t}}$ using $\hat{u}_{t}$. Under the null that $y_{\mathrm{t}}$ is $\mathrm{I}(0)$, Kwiatkowski, Phillips, Schmidt and Shin show that KPSS converges to a function of standard Brownian motion that depends on the form of the deterministic terms $D_{t}$ but not their coefficient values $\beta$. In particular, if $D_{t}=1$ then

$\operatorname{KPSS} \stackrel{d}{\longrightarrow} \int_{0}^{1} V_{1}(r) d r$

where $V_{1}(r)=W(r)+r W(1)$ and $W(r)$ is standard Brownian motion for $r \in[0,1]$. If $\mathrm{D}_{\mathrm{t}}=(1, t)^{`}$ then

$$
\text { KPSS } \stackrel{d}{\longrightarrow} \int_{0}^{1} V_{2}(r) d r
$$

where $V_{2}(r)=W(r)+r(2-3 r) W(1)+6 r\left(r^{2}-1\right) \int_{0}^{1} V_{2}(r) d r$. Critical values from the asymptotic distributions (4) and (5) must be obtained by simulation methods.

The stationary test is a one-sided right-tailed test so that one rejects the null of stationarity at the $100 \alpha \%$ level if the KPSS test statistic (3) is greater than the $100(1-\alpha) \%$ quantile from the appropriate asymptotic distribution (4) or (5). 


\section{b. Toda-Yamamoto Procedure}

Toda and Yamamoto (1995) propose a method that is used to estimate unrestricted VAR by the use of a Modified Wald test for restrictions on the parameters of the VAR $(k)$ model and estimates a VAR $[k+d m a x]$, where $k$ is the lag order of VAR and dmax is the maximal order of integration for the series in the system. The procedure of causality test of Toda and Yamamato (1995) is expressed as follows:

Let $\mathrm{y}_{t}=\left(\mathrm{y}_{1, t}, \ldots, \mathrm{y}_{p, t}\right)^{\prime}$ a vector constitutes of $\mathrm{p}$ variables and estimated by VAR $\left(\mathrm{k}+\mathrm{d}_{\max }\right)$, where $\mathrm{d}_{\max }$ is the lag order of integration of the following variables:

$$
y=A+A y+A y+\ldots+A y+e ; t=(k+d)+1, \ldots, T
$$

In equation (1) $\mathrm{e}_{t}$ is an i.i.d. sequence of n-dimensional random vectors with mean zero and covariance matrix $\sum \succ 0$ such that $E\left[e_{i, t}\right]^{2+\delta} \prec 0$ for some $\delta \prec 0$.

Equation (1) can be written as follows:

$\mathrm{y}_{\mathrm{t}}=\mathrm{Ayl}_{\mathrm{t}}+\mathrm{e}_{\mathrm{t}}, \quad \mathrm{t}=(\mathrm{k}+\mathrm{d})+1, \ldots, \mathrm{T}$

where $\mathrm{A}$ is a matrix defined as $\mathrm{A}=\left(\begin{array}{lll}\mathrm{A}_{0} & \mathrm{~A}_{1} \ldots \mathrm{A}_{\mathrm{k}+\mathrm{d}_{\max }}\end{array}\right)$ and $\quad \mathrm{yl}_{\mathrm{t}}=\left(\begin{array}{ll}1 \mathrm{y}_{\mathrm{t}-1}^{\prime} \ldots \mathrm{y}_{\mathrm{t}-\left(\mathrm{k}+\mathrm{d}_{\max }\right)} & )^{\prime}\end{array}\right.$

Let $y=\left(y_{k+d_{\text {max }}+1} y_{k+d_{\text {max }}+2} \ldots y_{T}\right) \Rightarrow y l=\left(y l_{k+d_{\text {max }}+1} y l_{k+d_{\text {max }}+2} \ldots y l_{T}\right)$

$\mathrm{e}=\left(\mathrm{e}_{k+d_{\text {max }}+1} \mathrm{e}_{k+d_{\text {max }}+2}, \mathrm{e}_{T}\right)$,

Equation (2) became as follows:

$Y=A y l+e$

The OLS estimator of $\mathrm{A}_{v}$ is: $A_{V}=\left(\left(y l y l^{\prime}\right)^{-1} \otimes I_{p}\right) \operatorname{vec}(y)$, where $A_{v}=\operatorname{vec}(A)$

$\sum_{A}=\Gamma^{-1} \otimes \sum, \quad \Gamma=\left(y l y l^{\prime}\right) / T^{*}, \quad M_{y l}=I_{T^{*}}-y l^{\prime}\left(y l y l^{\prime}\right)^{-1} y l, \quad \sum=y M_{y l} y^{*} T^{*} ; T^{*}=T-$

$\left(k+d_{\max }\right)$.

MWALD test is given by: $\lambda_{w}=T^{*}\left(R A_{v}\right)^{\prime}\left(R \sum_{A} R^{\prime}\right)^{-1}\left(R A_{v}\right)$ has an asymptotic Chi-square distribution with à $J$ degree of freedom if $\mathrm{p} \geq \mathrm{k}+\mathrm{d} . R$ is the matrix of dimension $(\mathrm{J}, \mathrm{q})$ and $q=p(1+p$ $\left.\left(k+d_{\max }\right)\right)$ and if $R A_{v}=0$.

Rambaldi and Doran (1996) show that MWALD test can be determined in a VAR regression by the use SUR (Seemingly Unrelated Regressions). In this case, equation (3) can be written as follows:

$\mathrm{y}^{\prime}=y l^{\prime} A^{\prime}+e^{\prime}$ 
By performing the operator vec in equation (4), it becomes:

$\operatorname{vec}\left(y^{\prime}\right)=\left(I_{p} \otimes y l^{\prime}\right) \operatorname{vec}\left(A^{\prime}\right)+\operatorname{vec}\left(e^{\prime}\right)$

Let $\alpha=\operatorname{vec}\left(A^{\prime}\right), \mathrm{Y}=\operatorname{vec}\left(\mathrm{y}^{\prime}\right)$ and $\mathrm{u}=\operatorname{vec}\left(\mathrm{e}^{\prime}\right)$, in equation (5) will be as follows:

$Y=\left(I_{p} \otimes y l^{\prime}\right) \alpha+u$

$E\left(u u^{\prime}\right)=\sum \otimes I_{T^{*}}$

Vector $\mathrm{Y}$ is the sum of $\mathrm{T}^{*}$ observations of $\mathrm{y}_{t}$ followed by $\mathrm{T}^{*}$ observations of $\mathrm{y}_{2}$ etc...until $\mathrm{T}^{*}$ of $\mathrm{y}_{p}$. Vector $\alpha$ is constituted of parameters of vector $\mathrm{A}_{v}$ but with a different order. Equations (6) and (7) are the components of SUR. The covariance matrix of $\alpha$ is given by:

$\sum_{\alpha}=\sum \otimes\left(\left(y l y l^{\prime}\right) / T^{*}\right)^{-1}$

Let $\mathrm{S}$ a matrix with $\mathrm{S} \hat{\alpha}=\mathrm{RA}_{v}$, hence $S \sum_{\alpha} S^{\prime}=R \sum_{A} R^{\prime}$

The coefficient $\lambda_{w}$ is equivalent to $(\mathrm{S} \hat{\alpha})^{\prime}\left(\operatorname{SV}(\hat{\alpha}) S^{\prime}\right)^{-1}(S \hat{\alpha})$, therefore $\lambda_{w}$ is the statistic of Wald pour le test des restrictions $\mathrm{S} \alpha=0$.

The advantage of this procedure is that it does not require knowledge of cointegration properties of the system. This test can be done even if there is no cointegration and/or the stability and rank conditions are not satisfied (Zapta and Rambaldi, 1997). Arithmetically, the trivariate framework of our case study can be expressed as follows:

$$
\begin{aligned}
& \ln G R_{t}=\alpha_{1}+\sum_{i=1}^{k+d \max } \beta_{1 i} \ln G R_{t-i}+\sum_{i=1}^{k+d \max } \beta_{1 i} \ln G E_{t-i}+\sum_{i=1}^{k+d \max } \beta_{1 i} \ln G D P_{t-i}+\mu_{1 t} \\
& \ln G E_{t}=\alpha_{2}+\sum_{i=1}^{k+d \max } \beta_{2 i} \ln G E_{t-i}+\sum_{i=1}^{k+d \max } \beta_{2 i} \ln G R_{t-i}+\sum_{i=1}^{k+d \max } \beta_{2 i} \ln G D P_{t-i}+\mu_{2 t} \\
& \ln G D P_{t}=\alpha_{3}+\sum_{i=1}^{k+d \max } \beta_{3 i} \ln G D P_{t-i}+\sum_{i=1}^{k+d \max } \beta_{3 i} \ln G E_{t-i}+\sum_{i=1}^{k+d \max } \beta_{3 i} \ln G R_{t-i}+\mu_{3 t}
\end{aligned}
$$

where LGR is the logarithm of real general government revenues, LGE is the logarithm of real general government expenditures; LGDP is the logarithm of real gross domestic product. Payne (1997) is the first who modeled government expenditure with gross domestic product for Canada and then for a panel of countries. Narayan and Narayan (2006) have also used the same framework for a panel of developing countries and later Hamdi and Sbia (2013) for a panel of GCC countries.

To summarize the theoretical framework, Toda-Yamamoto method is performed in two steps. The first step consists in determining the lag length $(k)$ of VAR model and the maximum order of integration $(d)$ of the time series variables in the system. After the selection of optimum lag length VAR $(k)$ and the order of integration $d$ max, a level VAR is estimated with a total of $[k+d m a x]$ lags. The second step requests the application the standard Wald tests on the first $(k)$ VAR coefficient matrix to make Granger causal inference using a chi square $\left(\chi^{2}\right)$ distribution. 


\section{EMPIRICAL RESULTS}

The empirical analysis is based on three steps. Firstly, we determine the order of integration of the series (dmax) and the optimal lag length k. To this end, we conduct Augmented Dickey-Fuller tests which will be confirmed by KPSS tests. Secondly, we determine the optimal lag length the model using the sequential modified LR test statistic (LR), Final prediction error (FPE), Akaike information criterion (AIC), Schwarz information criterion (SC), and Hannan-Quinn information criterion (HQ). The result of selecting optimal lag length of VAR indicates that lag order of VAR (k) is 2, for trivariate VAR. Thirdly, we augment the VAR by the maximum order of integration of the series (dmax) and then we test for any misspecification to ensure that the classical regression assumptions were not violated.

\section{a. Unit Root Test: ADF and KPSS}

We test for stationarity of the data series before proceeding with the Toda-Yamamoto Granger causality test. We employ an augmented Dickey-Fuller test on the time series in levels and differenced forms. Table 1 reveals the results of the stationarity analysis. The results show that we cannot reject the null hypothesis of unit roots for all variables in level forms. However, the null hypothesis is rejected when the ADF test is applied to the first differences of each variable. The first differences of the lnGDP, lnGR and lnGE, are stationary indicating that these variables are in fact integrated of order one, $I(1)$.

Further to the ADF tests, we employ the KPSS tests as indicated in table 1. Results show that government revenues, government expenditures and real GDP are non-stationary in their levels. These findings support those obtained from the ADF test.

Table 1: Unit Root Test

\begin{tabular}{|c|c|c|c|c|c|c|c|c|c|c|}
\hline \multirow{2}{*}{ Variables } & \multicolumn{2}{|c|}{ Greece } & \multicolumn{2}{|c|}{ Italy } & \multicolumn{2}{|c|}{ Ireland } & \multicolumn{2}{|c|}{ Spain } & \multicolumn{2}{|c|}{ Portugal } \\
\hline & Level & $1^{\text {st }}$ diff & Level & $1^{\text {st }}$ diff & Level & $1^{\text {st }}$ diff & Level & $1^{\text {st }}$ diff & Level & $1^{\text {st }}$ diff \\
\hline LGR & -2.08 & -2.44 & -2.18 & -1.73 & -1.53 & -3.10 & -3.07 & -2.58 & 1.14 & $-10.13 * * *$ \\
\hline LGE & -2.60 & $-4.88 * * *$ & -1.15 & $-4.77 * *$ & 0.29 & $-6.62 * * *$ & 0.24 & $-1.70 * *$ & -1.19 & $-2.33 * * *$ \\
\hline LGDP & 1.15 & 1.04 & -0.19 & -1.26 & 0.09 & -2.97 & 2.12 & -0.45 & -0.60 & $-2.97 * * *$ \\
\hline
\end{tabular}

KPSS

\begin{tabular}{|l|c|c|c|c|c|c|c|c|c|c|}
\hline \multirow{2}{*}{ Variables } & \multicolumn{2}{|c|}{ Greece } & \multicolumn{2}{|c|}{ Italy } & \multicolumn{2}{c|}{ Ireland } & \multicolumn{2}{c|}{ Spain } & \multicolumn{2}{c|}{ Portugal } \\
\cline { 2 - 11 } & Level & $\mathbf{1}^{\text {st }}$ diff & Level & $\mathbf{1}^{\text {st }}$ diff & Level & $\mathbf{1}^{\text {st diff }}$ & Level & $\mathbf{1}^{\text {st diff }}$ & Level & $\mathbf{1}^{\text {st }}$ diff \\
\hline LGR & $0.15^{* *}$ & $0.35^{*}$ & $0.13^{*}$ & 0.08 & $0.15^{* *}$ & 0.10 & 0.12 & 0.09 & $0.18^{* *}$ & $0.50^{* * *}$ \\
\hline LGE & $0.16^{* *}$ & $0.50^{* * *}$ & $0.16^{* *}$ & $0.36^{* * *}$ & $0.17^{* *}$ & $0.49^{* *}$ & $0.14^{*}$ & $0.13^{*}$ & $0.15^{* *}$ & $0.16^{* *}$ \\
\hline LGDP & $0.13^{*}$ & $0.17^{* *}$ & $0.16^{* *}$ & $0.46^{* *}$ & $0.17^{* *}$ & 0.10 & $0.17^{* *}$ & $0.16^{* *}$ & $0.16^{* *}$ & 0.48 \\
\hline
\end{tabular}

Notes: $* * *, * *$ and $*$ indicate significance at 1,5 and $10 \%$, respectively.

As our series are $\mathrm{I}(1)$, this means that, $d \max =1$. Further, the result of selecting optimal lag length of VAR indicates that lag order of VAR (k) is 2, for trivariate VAR. Therefore, we can estimate a VAR system in levels with a total of $d m a x+k$ lags for each country.

\section{b. Toda-Yamamato Granger Causality Tests}

As we mentioned above, a multivariate Granger causality tests based on the Toda and Yamamato (1995) procedure provides valid inference in the context of unstable, possibly cointegrated systems (Hamdi 2013). The results of these tests are presented in Table 2. 
Table 2: Toda and Yamamoto Results

\begin{tabular}{|l|c|c|c|c|c|}
\hline & Greece & Italy & Ireland & Spain & Portugal \\
\hline GE => GR & $19.84(0.00)^{* * *}$ & $0.96(0.62)$ & $00.34(0.85)$ & $00.07(0.97)$ & $9.73(0.00)^{* * *}$ \\
\hline GDP => GR & $01.83(0.40)$ & $3.39(0.18)$ & $00.72(0.70)$ & $11.52(0.00)^{* * *}$ & $2.32(0.33)$ \\
\hline GR => GE & $00.31(0.86)$ & $2.95(0.23)$ & $16.04(0.00)^{* * *}$ & $45.38(0.00)^{* * *}$ & $50.66(0.00)^{* * *}$ \\
\hline GDP => GE & $00.44(0.80)$ & $0.08(0.96)$ & $02.90(0.23)$ & $90.55(0.00)^{* * *}$ & $07.72(0.02)^{* *}$ \\
\hline GR=> GDP & $00.90(0.64)$ & $8.32(0.01)^{* *}$ & $01.45(0.49)$ & $06.50(0.03)^{* *}$ & $1.11(0.58)$ \\
\hline GE => GDP & $18.20(0.00)^{* * *}$ & $0.61(0.73)$ & $00.56(0.76)$ & $17.47(0.00)^{* * *}$ & $2.04(0.37)$ \\
\hline
\end{tabular}

Notes: $* * *$ and $* *$ indicate significance at 1 and 5 respectively.

The results of Granger non-causality test due to Toda and Yamamoto (1995) procedure are presented in table 2 and can be interpreted as follows. First, the results are not identical for the five countries; this is because of the heterogeneity of the economy of these countries.

Second, Portugal is the only country with a bidirectional relationship between the government revenue and government expenditure. This means that an increase in government expenditure rise government revenue and vice versa. Moreover, this implies that revenue and expenditure decisions are made independently in the 4 other countries. Furthermore, there is causal relationship running from GDP to government expenditure in Portugal.

For Italy, there is a unique unidirectional causality running from government revenue to GDP while a unidirectional causal relationship is running from government revenue to government expenditure in Ireland; thus there is an evidence of spend and tax hypothesis.

Turning now to Greece, results reveal a unidirectional relationship running from government expenditure to government revenue which support the 'spend and tax hypothesis' and another unidirectional causality running from government expenditure to GDP. The Greek fiscal policy based on expenditure is advantageous for the economy rather than another policy. Based on these findings, we can say that the current reforms adopted by the government, which are based on austerity, are harmful for the Greek economy and they cannot be considered as the proper policy responses.

Results for Spain reveal a bidirectional relationship between government revenue and GDP as well as bidirectional causality between government expenditure and GDP. This shows that an increase in revenue or in expenditure affects positively the output. Moreover, results show a unidirectional causal relationship between government revenue and government expenditure which support the tax-and-spend hypothesis suggested by Friedman (1978) and Buchanan and Wagner (1978).

\section{CONCLUSION}

This study has employed the Toda and Yamamoto (1995) procedure to determine the Granger no-causality tests between government revenues, government expenditures and growth for PIIGS countries. The tests are based upon annual time series for the period of 1995-2009. Toda and Yamamoto causality test based on trivariate VAR model indicates bidirectional relationship between government revenues and government expenditures in Portugal only. Greece is the only countries (with Portugal) in which government expenditures granger cause government revenues. For Italy there is a unique unidirectional relationship running from government revenues to GDP while a unique unidirectional relationship is running from government revenues to expenditures for Ireland. Results for Spain show a double bidirectional relationship running from government revenue to GDP and from government expenditures to GDP. Moreover, there exists a unidirectional causal relationship between government revenues and government expenditures.

\section{AUTHOR INFORMATION}

Helmi Hamdi, Senior research fellow CERGAM-CAE, Aix-Marseille University, France. E-mail: helmi_aix@yahoo.fr (Corresponding author) 
Rashid Sbia, Senior Economist at ERS, Ministry of Finance, Kingdom of Bahrain and research fellow at DULBEA, Solvay Business and Economics School, Belgium.

\section{REFERENCES}

1. Alesina, Alberto and Roberto Perotti. 1997. "Welfare State and Competitiveness", American Economic Review, American Economic Association, vol. 87(5):921-39.

2. Alesina, Alberto and Silvia Ardagna. 1998. "Tales of Fiscal Adjustments" Economic Policy, 13(27): 478545.

3. Afonso, Antonio and Ricardo M. Sousa. 2009. "The Macroeconomic Effects of Fiscal Policy in Portugal: a Bayesian SVAR Analysis" NIPE, WP 3/2009.

4. Baghestani, Hamid and Robert McNown. 1994. "Do Revenues or Expenditures Respond To Budgetary Disequilibria?” Southern Economic Journal, 61(2): 311-322.

5. Barro, Robert J. 1974. "Are Government Bonds Net Wealth” Journal of Political Economy. 82(6): 10951117.

6. Barro, Robert J. 1991a. "World Interest Rates and Investment" NBER Working Papers (3849), National Bureau of Economic Research, Inc.

7. Barro, Robert J. 1991b. "Economic Growth in a Cross Section of Countries" The Quarterly Journal of Economics, MIT Press, vol. 106(2): 407-43.

8. Barro, Robert J. and Xavier Sala-i_Martin. 1992. "Public Finance in Models of Economic Growth" Review of Economic Studies, vol. 59(4): 645-61.

9. Bayraktar, Nihal and Blanca Moreno-Dodson. 2010. "How Can Public Spending Help You Grow? An Empirical Analysis for Developing Countries" The World Bank Policy Research Working Paper (5367).

10. Blanchard, Olivier and Roberto Perotti. 2002. "An empirical characterization of the dynamic effects of changes in government spending and taxes on output", Quarterly Journal of Economics, 117(4): 13291368.

11. Blackley, Paul R. 1986. "Causality between revenues and expenditures and the size of the federal budget" Public Finance Quarterly, (14):139-56.

12. Bleaney, Micheal, Norman Gemmell and Richard Kneller. 2001. "Testing the Endogenous Growth Model: Public Expenditure, Taxation, and Growth over the Long Run," Canadian Journal of Economics, 34, 3657.

13. Buchanan James M. and Richard W. Wagner. 1978. "Dialogues concerning Fiscal Religion" Journal of Monetary Economics, (4): 627-636.

14. Burnside Craig and David Dollar. 2000. “Aid, Policies and Growth” American Economic Review, American Economic Association, vol. 90(4): 847-868.

15. Burnside Craig and David Dollar. 2004. “Aid, Policies and Growth” American Economic Review, American Economic Association, vol. 94(3): 781-784.

16. Fatás, Antonio and Ilian Mihov. 2001. "The effects of fiscal policy on consumption and employment: theory and evidence" CEPR Discussion Paper No. 2760.

17. Friedman, Milton. 1978. "The Limitation of Tax Limitation" Policy Review, 5(78): 7-14.

18. Giavazzi Francesco and Marco Pagano. 1990. "Can Sever Fiscal Contractions Be Expansionary? Tales of Two Small European Countries", NBER Working paper (3372), National Bureau of Economic Research, Inc.

19. Gupta, Sanjeev, Benedict Clements, Emmanuele Baldacci and Carlos Mulas-Granados. 2005. "Fiscal Policy, expenditure composition and growth in low-income countries", Journal of International Money and Finance, 24, 441-463.

20. Hamdi H (2013), Testing Export-led Growth Puzzle for Morocco and Tunisia: New Evidence using the Toda and Yamamoto procedure Economics Bulletin, 2013, Vol. 33 No. 1 pp. 677-686.

21. Hamdi H and Sbia R (2013). Re-Examining Government Revenues, Government Spending, And Economic Growth in GCC Countries. Journal of Applied Business Research. Forthcoming.

22. Kouretas, Georgios P. and Prodromos Vlamis. 2010. "The Greek Crisis: Causes and Implications" Panoeconomicus, (4): 391-404.

23. Kumar, Manmohan, Daniel Leigh, and Alexander Plekhanov. 2007. "Fiscal Adjustments: Determinants and Macroeconomic Consequences" IMF Working Paper 07/178. 
24. Manage, Neela and Michael Marlow. 1986. "The causal relation between federal expenditures and receipts" Southern Economic Journal: 617-29.

25. Meltzer, Allan. H., Scott. F Richard. 1981. "A Rational Theory of Size of Government” The Journal of Political Economy, 89 (5): 914-927.

26. Miller, Stephen M. and Frank S. Russek. 1990. “Co-integration and error correction models: temporal causality between government taxes and spending” Southern Economic Journal: 33-51.

27. Miller, Stephen M. and Frank S. Russek. 2003. "The Relationship Between Large Fiscal Adjustment And Short-Term Output Growth Under Alternative Fiscal Policy Regimes" Contemporary Economic Policy, Western Economic Association International, vol. 21(1): 41-58.

28. Musgrave, Richard. 1966. "Principles of Budget Determination". H. Cameron and W. Henderson (eds.), Public Finance Selected Reading. New York: Random House, 15-27.

29. Narayan, Paresh K. and Seema Narayan. 2006. "Government Revenue and Government Expenditure Nexus: Evidence from Developing Countries” Applied Economic, (38): 285-291.

30. Owoye, Oluwole. 1995. "The Causal Relational between Taxes and Expenditures in the G7 countries: Cointegration and Error-correction Models". Applied Economics, 2(1): 19-22.

31. Payne, James E. 2003. "A survey of the international empirical evidence on the tax-spend debate" Public Finance Review, (31): 302-23.

32. Peacock, Alan T. and Jack Wiseman. 1961. The Growth of Public Expenditure in the United Kingdom. Princeton University Press for the National Bureau of Economic Research, Princeton, NJ.

33. Peacock, Alan T. and Jack Wiseman. 1979. "Approaches to the Analysis of Government Expenditure Growth". Public Finance Review, (7): 3-23.

34. Perotti, Roberto. 1999. "Fiscal Policy in Good Times and Bad", Quarterly Journal of Economics, 114(4): 1399-1436.

35. Prokopijević, Miroslav. 2010. "Euro Crisis” Panoeconomicus, (3): 369-384.

36. Ram, Rati. 1988. "Additional Evidence on Causality between Government Revenue and Government Expenditure" Southern Economic Journal, 54, 763-769.

37. Ramey, Valerie A. and Matthew D. Shapiro. 1998 "Costly capital reallocation and the effects of government spending” Carnegie-Rochester Conference Series on Public Policy, Elsevier, Vol. 48(1):14594.

38. Toda, Hiro Y. and Taku Yamamoto. 1995. "Statistical inference in vector autoregression with possibly integrated process" Journal of Econometrics, (66): 225-250.

39. Zapata, Hector O. and Alicia N. Rambaldi. 1997. "Monte Carlo evidence on cointegration and causation" Oxford Bulletin of Economics and Statistics, (9): 285-298. 